taken to be an advantage on the strength of Mr. Fergusson's authority, which, in matters of operativ? manipulation, must surely be supreme.

But a much graver and more uncertain question connected with Mr. Fergusson's method of performing lithotrity is, whether he is right in recommending the instant removal of the débris in cases of crushing a stone of large size. We should remember that, in this case, the fragments are of uncertain size (for, after all, the width of the opening of the lithotrite only shows one diameter of the fragment); their angles arefresh and sharp; and the bladder has perhaps already borne as much manipulation as is prudent. Further, we should remember that (with the exception of the small shank of Mr. Fergusson's scoop) this is the method which was originally adopted, and abandoned on account of the pain, laceration of the urethra, and after-complications which ensued. It would, perhaps, be invidious to quote one author against another; but it is allowable to say, in general terms, that lithotritists of the largest experience, who have had ample opportunities of knowing the minutest particulars of Mr. Fergusson's system of manipulation, still avow their preference for the plan of awaiting the spontaneous expulsion of fragments. Evidently, therefore, the question resolves itself into one of experience ; and, as to Mr. Fergusson's experience, his expressions were rather more vague than we could have wished. He said:

"In the last sixty cases I have adopted this practice generally, and, with few exceptions, have had every reason to be satisfied. Occasionally, when over-anxious for a rapid cure, I have extracted fragments rather too large to come readily along the urethra, particularly in the prostatic or membranous portion, or at the triangular ligament. In some, when the urethra nearest the neck of the bladder has been rather roughly used, there has been considerable irritation ; in others, even under such circumstances, there has been no irritation whatever; and in many instances I have been able to effect in one or two operations within ten days what, according to custom, would take weeks, or possibly months. I have done, in fact, by a precise surgical manipulation, that which according to ordinary rule is left entirely to chance. Experience has taught me that it is almost hopeless to trust to chance in all such cases; that in many instances the fragments may be weeks, or months, in coming away, even with attempts to coax them through catheters with large eyes and other instruments devised for the purpose. Here are the fragments of stone crushed in a man whose bladder acted regularly, yet only a few of these passed spontaneously; all the rest were removed by the scoop in question in three or four operations. From first to last there was not a single bad or even troublesome symptom. The patient was detained scarcely an hour in bed beyond his regular period of rest. I never saw one suffer less distress; yet, before he came under my notice, he had been strongly urged by an eminent surgeon to submit to lithotomy."

If Mr. Fergusson had preserved such notes of his cases as would have enabled him to say precisely in how many cases he had removed the dibris at the time of operation, how many of these had had troublesome symptoms, what these symptoms precisely were, and what were their results, it would have been more satisfactory, and would have put us in a better position to draw a comparison between his method (or rather his revival of the old method) and that which is in more general use. What struck us, after hearing what Mr. Fergusson said on this matter, was, that if a patient with stone were fortunate enough to be in Mr. Fergusson's hands, he might perhaps have his cure somewhat accelerated (though probably at the risk of increased suffering at the time of operation) by this plan of removing the fragments; but that, if he had fallen into the hands of some less ingenious manipulator, he would be lucky if his surgeon were not in so great a hurry to send him away cured. In fact, we could not repress a latent suspicion that the old adage of "Festina lente" might, after all, express the better policy.

\section{Iettsomian 色ectures}

on

\section{MIDWIFERY AND DISEASES OF WOMEN.}

Delivered before the Medical Society of London.

nY

C. H. F. ROUTH, M.D.,

PHYSICIAN TO THE SAMARITAN HOSPITAL, YOR WOMEN AND CHILDREN.

\section{Lecture III. (Continued.)}

'The Treatmext of Fibrocs 'Tumovrs.

2. Treatment by Gastrotomy. I have now to speak of another mode of cure ; viz., gastrotomy. At the outset, I may say that, in the consideration of the cases in which this operation has been had recourse to, we labour under three disadvantages. 1. Several cases, I know, have been unpublished; and, therefore, the instances quoted fall short of the actual number of examples that have occurred. 2. The records of these cases are by no means full. 'The details are often so meagre as to leave little room for philosophical deductions. 3. It is possible, on the other hand, that I am exaggerating the number of examples, and that the same cases are repeated. 'This was undoubtedly so with one of Dr. Clay's cases; which that gentleman, however, kindly explained to me. In Atlee's cases, again, it is just possible that this source of error exists. In such instances, however, the mistake is due to the imperfect records and disagreements between them, more especially in regard to dates of recovery, of death, age, married or single state, size, weight of the tumour; in which particulars the records, otherwise resembling each other, disagree.

Altogether, gastrotomy for fibrous tumour has been performed forty-eight times. In fifteen cases, however, the tumour, either in whole or in part, was not removed. In the remaining thirty-three, the entire or part of the tumour was removed. 'This resumé admits at once of division into two classes.

1. The cases of uterine tumour in which gastrotomy was performed, and extirpation not completed, were fifteen. 'These include four of Dr. W. I. Atlee, one of Dr. (lutler, one of Mr. Lane, one of Mr. Lizars, one of Dr. R. D. Massey, one of Dr. N. Smith, one unknown, one of Mr. Walne, one of Dr. Deane, and three of Mr. I. B. Brown. (See Table II.)

In five of these, the exact locality of the tumour is not given: two were fibrocystic; one extrauterine; one a double example-i.e., intrauterine and extrauterine; six parietal, one of these last being combined with pregnancy.

Of these fifteen cases, eight recovered from the operation. But, of these, three subsequently died; one six months afterwards, from erysipelas; another seven 
TABLE II.-Cases of Uterine Tumour in which Gastrotomy was performed, and Extirpation not completed.

\begin{tabular}{|c|c|c|c|c|c|c|}
\hline No. & $\begin{array}{l}\text { Operator and } \\
\text { Reference. }\end{array}$ & Age & Previous History, eic. & Steps of Operation. & Progress. & Final Result. \\
\hline 1 & $\begin{array}{l}\text { Dr. W. L. } \\
\text { Atlee, Phila- } \\
\text { delphia. } \\
\text { Am. Journ. of } \\
\text { Ared. Sci., } \\
\text { April 1855. } \\
\text { Clay's Kiwisch, } \\
\text { Table iv. }\end{array}$ & 33 & $\begin{array}{l}\text { Single. Tumour noticed four years ago, } \\
\text { since which irregular. Tapped, and blood } \\
\text { only escaped. Uterine sound passed } \\
\text { two inches and a half only. }\end{array}$ & $\begin{array}{l}\text { Operated May 22, } 1849 \text {. Incision } \\
\text { from umbilicus to near pubes. A } \\
\text { syphon tent placed in lower part } \\
\text { of wound. No adhesion. Wound } \\
\text { united by interrupted and twisted } \\
\text { sutures. }\end{array}$ & $\begin{array}{l}\text { Recovered oper- } \\
\text { ation, and sat } \\
\text { up nine days } \\
\text { afterwards. }\end{array}$ & $\begin{array}{l}\text { Died } 6 \text { months } \\
\text { afterwards from } \\
\text { erysipelas. }\end{array}$ \\
\hline 2 & $\begin{array}{l}\text { Ditto. } \\
\text { Ibid. Ibid. }\end{array}$ & 43 & $\begin{array}{l}\text { Single. No aceount of duration, ete. } \\
\text { Tumour after operat. found to be uterine, } \\
\text { incorporated with large cystiform bodies. } \\
\text { Fibrocystic. }\end{array}$ & $\begin{array}{l}\text { Operated Oct. } 13,1849 \text {. Incision } \\
\text { from near umbilicus to pubes. } \\
\text { No adhesions. }\end{array}$ & $\cdots$ & $\begin{array}{l}\text { Recorered. } \\
\text { Died four years } \\
\text { afterwards. }\end{array}$ \\
\hline $\mathbf{3}$ & $\begin{array}{l}\text { Ditto. } \\
\text { Ibid. Iuid. }\end{array}$ & 41 & $\begin{array}{l}\text { Unmarnied. Woman of colour. No ac- } \\
\text { count of duration, ete. Uterine tumour } \\
\text { not adherent. }\end{array}$ & $\begin{array}{l}\text { April } 13,1850 \text {. Incision from near } \\
\text { umbilicus to pubes. Intestines } \\
\text { were forced out, and could scarcely } \\
\text { be returned, in consequence of the } \\
\text { anmsthetic agent inducing a cata. } \\
\text { leptic coud. of muscular parietes. }\end{array}$ & $\cdots$ & $\begin{array}{l}\text { Recovered. } \\
\text { Still living, } \\
\text { April 1855. }\end{array}$ \\
\hline 4 & $\begin{array}{l}\text { Ditto. } \\
\text { Ibid. Ibid. }\end{array}$ & 42 & $\begin{array}{l}\text { Married. No account of duration. An } \\
\text { extrauterine fibrous tumour. }\end{array}$ & $\begin{array}{l}\text { Operated Dec. } 20,1851 \text {. During } \\
\text { the operation, an abscess deep in } \\
\text { the abdomen was opened and a } \\
\text { quantity of pus discharged. }\end{array}$ & . & $\begin{array}{l}\text { Recorered. } \\
\text { Still living, } \\
\text { April, 1855. }\end{array}$ \\
\hline 5 & $\begin{array}{c}\text { Dr. Cutter, } \\
\text { of Woburn. } \\
\text { Am. Journ. of } \\
\text { Med. Sci., } \\
1854 .\end{array}$ & 33 & $\begin{array}{l}\text { Single. First noticed tum. 7 yrs. ago; } 2 \text { yrs. } \\
\text { afterw. very percept. In 1. hypogastrium. } \\
\text { Developm. attended w. attacks of periton. } \\
\text { itis \& dysuria, leading to nse of catheter. } \\
\text { Catam. regular. lately accomp. w. hæmorr. } \\
\text { Soreness of abdomen followed by ascites, } \\
\text { for which she was twice tapped since her } \\
\text { health failed, Feb. 1853. Tumour felt low } \\
\text { per vaginam. Simpson's sound penetrated } \\
5 \text { in. Case pronounced hopeless, but wom. } \\
\text { so urgent for operat., it was tried. Cervix } \\
\text { \& fundns uteri involved. A large turnour } \\
\text { from wh. several smaller ones projected in } \\
\text { cavity of abdomen. Parietal. }\end{array}$ & $\begin{array}{l}\text { Operation performed Oct. } 12,1853 . \\
\text { Incision } 8 \text { inches in median line. } \\
\text { Tumour found to be fibrous. Con. } \\
\text { nexions forbad removal. Tumour } \\
\text { punctured and bled profusely, so } \\
\text { as to require ligature. Wound } \\
\text { closed. }\end{array}$ & $\begin{array}{l}\text { Several days } \\
\text { suffered but lit- } \\
\text { tle pain under } \\
\text { use of opium. }\end{array}$ & $\begin{array}{l}\text { Died } 12 \text { days } \\
\text { after operntion. } \\
P . M \text {. Verylittle } \\
\text { peritonitis. In- } \\
\text { tegum ts healed } \\
\text { and opening in } \\
\text { uterus also. }\end{array}$ \\
\hline 0 & $\begin{array}{c}\text { Mr. Tane. } \\
\text { I.ondon. } \\
\text { Clav's Trans. } \\
\text { of Kivisch on } \\
\text { Dis.ofOraries. }\end{array}$ & 22 & $\begin{array}{l}\text { Single. Disease of many years' duration. } \\
\text { Health good. Found after operation to } \\
\text { be a large fleshy tubercle of uterus. Pa. } \\
\text { rietal. }\end{array}$ & $\begin{array}{l}\text { Operated } 184 \% \text {. Incision from um. } \\
\text { bilicus to pubes. Tumour too much } \\
\text { connected with uterus for remoral. } \\
\text { Wound closed by } 15 \text { interrupted } \\
\text { sutures not through peritoneum. }\end{array}$ & Wound healed. & $\begin{array}{l}\text { Recovered, but } \\
\text { died five weeks } \\
\text { after operation. } \\
\text { Suicide suspec- } \\
\text { ted. A } 3 \text { months } \\
\text { feetus found in } \\
\text { utero. }\end{array}$ \\
\hline $\boldsymbol{7}$ & $\begin{array}{c}\text { Mr. Lizars. } \\
\text { of Edinburgh. } \\
\text { Liz. Ext. of } \\
\text { Dis. Oraries, } \\
\text { pp. 19-20. }\end{array}$ & 34 & $\begin{array}{l}\text { Unmarried. Tumour observed six years } \\
\text { ago. Catamenia irregular; urine occasi- } \\
\text { onally sulpressed; general health good; } \\
\text { bnd considerable muscular strength, but } \\
\text { earnostly entreated something might be } \\
\text { done to relieve her. }\end{array}$ & $\begin{array}{l}\text { Operated April } 21,1825 \text {. Incision } \\
\text { from sternum to pwbes. The tll. } \\
\text { mour was pierced and incised } \\
\text { twice, but nothing but pure blood } \\
\text { followed. The wound was then } \\
\text { closed by sutures and adhesive } \\
\text { straps. }\end{array}$ & $\cdots$ & $\begin{array}{l}\text { Recovered in a } \\
\text { fortnight. Died } \\
\text { Nov. 28, of Apo- } \\
\text { plexy. Edin- } \\
\text { burgh Journal, } \\
\text { March 1851. }\end{array}$ \\
\hline 8 & \begin{tabular}{|c|} 
Dr. R. D. \\
Massey. \\
Americe. \\
Hamilton'sRep.
\end{tabular} & .. & $\begin{array}{l}\text { No account of duration, etc. After oper- } \\
\text { ation found to be a tumour in uterine } \\
\text { walls. Parietal. }\end{array}$ & Operated 1350. Large incision. & $\cdots$ & $\begin{array}{l}\text { Died from ex- } \\
\text { haustion four- } \\
\text { teen hours after- } \\
\text { wards. }\end{array}$ \\
\hline 9 & $\begin{array}{c}\text { Dr. N. Smith. } \\
\text { America. } \\
\text { Lyman's Rep.. } \\
\text { Boston, 1856. } \\
\text { Case 248. }\end{array}$ & *. & No aecount of duration. & $\begin{array}{l}\text { Long incision. Vterus found to } \\
\text { be involved, and constituting lar. } \\
\text { gest part of tumour. Wound } \\
\text { closed. }\end{array}$ & $\cdots$ & liecovered. \\
\hline 10 & \begin{tabular}{|c|} 
Unknown. \\
Germany. \\
Scanzoni's \\
Beiträge. 1858. \\
Sim's Table.
\end{tabular} & 36 & Hard tumour in abdomen, with ascites. & $\begin{array}{l}\text { Found to be cancerous tumour } \\
\text { connected with uterus. Wound } \\
\text { closed. }\end{array}$ & $\cdots$ & $\begin{array}{l}\text { Death in three } \\
\text { days. }\end{array}$ \\
\hline 11 & $\begin{array}{l}\text { Mr. Walne, of } \\
\text { London. } 1844 . \\
\text { Med. Gaz., } \\
\text { Mar. 10. p. } 47 .\end{array}$ & 45 & $\begin{array}{l}\text { Uterine disease ; fibrous tumour; cysts } \\
\text { of ovary, solid and fluid. Parietal. }\end{array}$ & Long incision. & . & $\begin{array}{l}\text { The tum'r rest- } \\
\text { ing agst.incision } \\
\text { was supposed to } \\
\text { have caused in- } \\
\text { flammution and } \\
\text { death. }\end{array}$ \\
\hline 12 & $\begin{array}{c}\text { Mr. J. B. } \\
\text { Brown. } \\
\text { London Home. }\end{array}$ & 43 & $\begin{array}{l}\text { Admitted Oct. 12, } 1360 \text {. Tumour first no- } \\
\text { ticed right side of abdomen, about size } \\
\text { of an egg, 9 years ago; increased gradu- } \\
\text { ally; general health good. Examination. } \\
\text { Large mass of fibrous tumour discovered } \\
\text { within the uterus; also a fibrous tumour } \\
\text { attached externaly to fundus, to be felt } \\
\text { through parietes. After the first operat. } \\
\text { the tumour was found to be growing, and } \\
\text { having a feeling of fluctuation not to be } \\
\text { defined. Filiroid, vascular, intrauterine } \\
\text { and extrauterine. }\end{array}$ & $\begin{array}{l}\text { First operation, os uteri and cervix } \\
\text { uteri incised on each side, under } \\
\text { chloroform. } \\
\text { Jan. } 24.1861 \text {. Exploratory incision } \\
\text { made through abdominal parietes. } \\
\text { A large fibrocellular tumour dis- } \\
\text { covered by which whole pelvis was } \\
\text { modelled, and which had grown } \\
\text { above brim, and was so firm as to } \\
\text { be immovable. Fluctuation evi- } \\
\text { dent. On cutting in, tumour was } \\
\text { found to be made up of n number } \\
\text { of engorged vessels which hled } \\
\text { freely. The incision was deep. } \\
\text { Brought together by } 3 \text { silver su- } \\
\text { tures. Ahd. -lnsed in ord. wav. }\end{array}$ & $\begin{array}{l}\text { Not a bad symp. } \\
\text { tom aftergastro- } \\
\text { tomy. Wound } \\
\text { healed. I.eft } \\
\text { the IIome. }\end{array}$ & $\begin{array}{l}\text { Recovered im- } \\
\text { perfect lealth. } \\
\text { Tumour pas- } \\
\text { sive, no incoir- } \\
\text { venience. }\end{array}$ \\
\hline
\end{tabular}


TABLE II.-Continued.

\begin{tabular}{|c|c|c|c|c|c|c|}
\hline No. & $\begin{array}{c}\text { Operator and } \\
\text { Reference. }\end{array}$ & Age & Previous History, etc. & Steps of Operation. & Progress. & Final Result. \\
\hline 13 & $\begin{array}{c}\text { Mr. I. B. } \\
\text { Brown. } \\
\text { London Home. } \\
\text { Communicated }\end{array}$ & 30 & $\begin{array}{l}\text { Married four years. Adinitted Nov. } 26, \\
1862 \text {. No children. Always healthy till } \\
\text { six years ago, when she first perceived the } \\
\text { tumour. This increased at each epoch, } \\
\text { subsiding with its cessation. Catamenia } \\
\text { copious. Health failing in l8ti0,was tapped. } \\
\text { Two quarts of dark fluid drawn off. Cata- } \\
\text { menia regular. Examination. Large mul- } \\
\text { tilocular ovarian tumour diagnosed; also } \\
\text { what appeared to be undoubted umbilical } \\
\text { hernia of omentum. Fibrocystic. }\end{array}$ & $\begin{array}{l}\text { Operated Dec. 11, 1862. After pri- } \\
\text { mary incision, large quantity of } \\
\text { ascitic tluid escay,ed. A cyst then } \\
\text { came into view, which looked like } \\
\text { iutestine, and on exam. tumour } \\
\text { was fnd. to be composed of several } \\
\text { hurd masses (like scirrhus) and } \\
\text { very adherent in every direction. } \\
\text { It was attached to the whole omen. } \\
\text { tun, liver, and uterus, being also } \\
\text { quite immovable. A quart of pale } \\
\text { yellow fluid was drawn off from } 2 \\
\text { of the cysts, and the wound closed } \\
\text { with silver sutures. }\end{array}$ & $\begin{array}{l}\text { Weut on well } \\
\text { till } 1 \text { rth, when } \\
\text { coughing vio- } \\
\text { lently, wound } \\
\text { was forced open, } \\
\text { serous fluid com. } \\
\text { ing out. Contd. } \\
\text { for a few days. } \\
\text { Dec. } 26 \text {, small } \\
\text { abscess opened } \\
\text { at upler part of } \\
\text { wound. Stimu- } \\
\text { lauts, wine, and } \\
\text { acid given. Tu- } \\
\text { mour refilling. } \\
\text { Sickness. Wnd. } \\
\text { gaping. }\end{array}$ & $\begin{array}{l}\text { Died, January } \\
6,1863 \text {. }\end{array}$ \\
\hline 14 & $\begin{array}{c}\text { Mr. I. B. } \\
\text { Jrown. } \\
\text { Ditto. }\end{array}$ & 41 & $\begin{array}{l}\text { Yarried } 7 \text { yrs.; no child.; } 2 \text { miscarr. Ad- } \\
\text { mitted Feb. 2, 1863. Irregul. since marr. } \\
\text { 18 niths. since had severe pain, 1. hip, wh. } \\
\text { persisted spite of treatm. Six mths. after } \\
\text { perceived a sm. tumour in r. ovn. region. } \\
\text { This increas'd gradually \& became central. } \\
\text { Iatteriy menstr. more irregul., suppressed } \\
\text { since Nov. last. Whole abdomen filled w. } \\
\text { tumour larger than full twin pregnancy. } \\
\text { Irregular in outline, w. } 2 \text { small outgrowths } \\
\text { superiorly. In parts indistinct fluct. or } \\
\text { elasticity. Pelvis was so filled up with } \\
\text { tumour and os so drawn up behind pubis } \\
\text { that sound could not be introduced. Gen- } \\
\text { eral health bad. Patient urgent for oper- } \\
\text { ation. Dingnosis obscure. Parietal. } \\
\text { Fibroid complicated with pregnancy. }\end{array}$ & $\begin{array}{l}\text { Feb. :6. Exploratory incision, } \\
3 \text { inches long. Tumour found very } \\
\text { vascular, more like muscle than } \\
\text { cyst of ovary. Trochar plunged in } \\
\text { to make sure, giving exit only to } \\
\text { a little blood. Closed by silver } \\
\text { wire. Abdominal parietes also. }\end{array}$ & $\begin{array}{l}\text { Some tympan- } \\
\text { itis, yet prog. } \\
\text { well till Mar. 3. } \\
\text { when she had 8 } \\
\text { rigor; fever per- } \\
\text { sisted till lith. } \\
\text { 13th,inflammtn. } \\
\text { of tissues around } \\
\text { right eye. Insen- } \\
\text { sible; tender- } \\
\text { ness of abdo. } \\
\text { men. Fœtus } \\
\text { carne away. } \\
\text { broil, involving wl } \\
\text { o left side, also occ } \\
\text { pregnated uterus, a } \\
\text { way contracted. }\end{array}$ & $\begin{array}{l}\text { Died exhausted, } \\
\text { 17th. P.M. } 2 \text { pts. } \\
\text { of pus in perito- } \\
\text { neum. Tumour } \\
\text { adherent to pel- } \\
\text { yic fascia, and to } \\
\text { about } 2 \text { square } \\
\text { inches of liver. } \\
\text { Tumour size of } \\
\text { a peck basket, } \\
\text { with smooth \& } \\
\text { regular surface, } \\
\text { with two small } \\
\text { lumps of size of } \\
\text { hole left side of } \\
\text { upying position } \\
\text { aud half tumour. } \\
\text { jeveral purulent }\end{array}$ \\
\hline 15 & $\begin{array}{c}\text { Dr. Dean. } \\
\text { Brit. Med. and } \\
\text { Surg. Journ., } \\
39,221 . \text { Oct. } \\
1848 . \text { Amer. } \\
\text { Med.and.Surg. } \\
\text { Journ., vol. } 43, \\
258 .\end{array}$ & . & $\begin{array}{l}\text { A globular symmetrical tumour, resting on } \\
\text { pubis in front and sacrum behind. Raised } \\
\text { in recumbent position and free impulse } \\
\text { given to it. In erect immoveable. Iength } \\
\text { jerhaps } 8 \text { or } 9 \text { in. long by } 5 \text { or } 6 \text { brd. Seems } \\
\text { to spring from right ovary, still might be } \\
\text { uterine. Functions of uterus normal, no } \\
\text { deviation. No pain, but increasing rapidiy. } \\
\text { Uterine. Parietal. }\end{array}$ & $\begin{array}{l}\text { Iucision made on the left side of } \\
\text { umbilicus, carried down to pubes. } \\
\text { Round polished solid tum. expos. } \\
\text { covered with very large vessels. No } \\
\text { adhesions. Intestiues forced out. } \\
\text { Found to be a solid fibrous tumour } \\
\text { of uterus involving left half. Oper- } \\
\text { ntion stopped after consultation, } \\
\text { and parts returned. No bleeding } \\
\text { of any note occnrred. }\end{array}$ & $\begin{array}{l}\text { Inflummation, } \\
\text { folld. with spas- } \\
\text { modic twitch- } \\
\text { ings which con- } \\
\text { tinued till 8th } \\
\text { day; removed by } \\
\text { depletion. }\end{array}$ & $\begin{array}{l}\text { Recovered in a } \\
\text { fortnight. }\end{array}$ \\
\hline
\end{tabular}

months afterwards, of apoplexy. The third, one of the fibro-cystic disease cases, died four years afterwards.

The remaining seven died. In two of these, the tumour was combined with pregnancy. One died five weeks after the operation, and there was some reason to suspect suicide. 'The second seems to have died of peritonitis. One died of slight peritonitis, in twelve days ; another, of exhaustion, in fourteen hours after the operation. Another died of inflammation of the tumour; one of abscess. The cause of death in the last is not stated.

The first two fatal cases here mentioned should clearly be excluded. We cannot doubt that the diagnosis was most difficult, if not impossible, during life. This we are assured of from the character of those in whose practice the cases occurred. Still, if the principle so forcibly insisted upon by Dr. Greenhalgh had been adopted, and in which I fully concurnever to operate unless you can introduce the sound in uterum - which was in one of these examples, at least, tried several times, and without success, these cases would not have been operated upon. Thus we have thirteen cases and five deaths-a mortality which seems to justify the operation, if an operation be imperatively called for. One of the fibro-cystic cases, indeed, recovered and lived four years afterwards. It is not to be presumed, therefore, that she was otherwise than benefited from the operation.

[To be continued.]

\section{Illustrations}

of

\section{HOSPITAL PRACTICE: METROPOLITAN AND PROVINOTAL.}

\section{BIRMINGHAM GENERAL HOSPITAL.}

HEMIPLEGIA ON THE RIGHT SIDE, WITH LOSS OF SPEECH.

Cases under the care of JAMES RUsseld, M.D.

IN a very interesting letter to this Journal (May 21st, 1864), with the title prefixed to the present paper, Dr. Hughlings Jackson makes the following statement: "I have noticed that when defect of speech occurs with hemiplegia, the hemiplegia is, so far as my experience goes, invariably on the right side." Any statement by so laborious and accurate a student of cerebral pathology as Dr. Jackson must be received with much respect; and he had interested me in the subject by a conversation a short time before his letter appeared. I am, therefore, led to present the result of an examination of my casebooks, as a contribution towards the inquiry which Dr. Jackson invites.

The cases from which the following abstracts are made have, of course, been reported entirely without regard to the question raised by Dr. Jackson; there. fore, if the testimony they afford be sometimes de. fective, it has the advantage of being unprejudiced. 